\title{
Effect of Mixing on the Density and Chlorophyll A Content on Botryococcus Sp.
}

\author{
Mazhatarmizi Harun*, Hazel Monica Matias Peralta, Nurul Huda Gonawan and Zarina \\ Shahri
}

\begin{abstract}
Department of Technology and Natural Resources, Faculty of Applied Sciences and Technology, Universiti
Tun Hussein Onn Malaysia, Pagoh Campus, Km 1, Jalan Panchor, 84600 Pagoh, Johor, Malaysia
\end{abstract}

Received 30 September 2017; accepted 20 February 2018; available online 1 August 2018

DOI: https://10.30880/jst.2018.10.02.004

\begin{abstract}
Optimization of the growth of microalgae is essential due to demand for high biomass yields. In addition, the methods to estimate the growth (as cell density or biomass) of microalgae are tedious. The normal methods include cell counts, optical density, chlorophyll a and ash free dry weight. However, at least two of these methods were done together for every growth experiment to get a better result. Therefore, this study investigates the effect of mixing as one of the many factors that determines the growth of microalgae, Botryococcus sp. In addition, three different methods to estimate the growth (in terms of cell density or biomass) will be utilized. Three different treatments on the effect of mixing were employed (T1 using aeration; T2 manual hand shake two times daily; T3 no aeration and shaking) for these experiments. The experiment was carried out under outdoor conditions with temperature ranging from $25.8^{\circ} \mathrm{C}$ to $35.5^{\circ} \mathrm{C}$, light intensity from from 200 Lux to $18000 \mathrm{Lux}$ and $\mathrm{pH}$ of 7 to 8 units for 24 days using Bold basal medium (BBM) as growth media. Microalgae biomass was estimated by optical density, chlorophyll a and cell count using haemocytometer. The highest density of Botryococcus sp. was achieved (10.74 x $10^{6}$ cell $\mathrm{ml}^{-1} \mathrm{day}^{-1}$; OD of 3.246 at $680 \mathrm{~nm} ; 0.7843 \mathrm{mg} \mathrm{L}^{-1} \mathrm{day}^{-1}$ chlorophyll a) with aeration. Whereas, the lowest $\left(2.78 \times 10^{6}\right.$ cell ml$^{-1}$ day $^{-1}$; od $1.007(680 \mathrm{~nm})$; chlorophyll a $0.1586 \mathrm{mg} \mathrm{L}^{-1}$ day $\left.^{-1}\right)$ and $\left(3.07 \times 10^{6}\right.$ cell ml $^{-1}$ day $^{-}$ 1; od $0.999(680 \mathrm{~nm})$; chlorophyll a $\left.0.1545 \mathrm{mg} \mathrm{L}^{-1} \mathrm{day}^{-1}\right)$ with shaking and no aeration, respectively. There exist a positive linear relationship between cell counting and optical density $\left(\mathrm{R}^{2}=0.96\right)$; cell count and chlorophyll a $\left(\mathrm{R}^{2}=0.95\right)$; and optical density and chlorophyll a $\left(\mathrm{R}^{2}=0.98\right)$ were observed. The result of this study suggested that constant aeration is required by the microalgae, Botryococcus sp. for growth in terms of cell density and biomass.
\end{abstract}

Keyword: Botryococcus sp.; optical density; chlorophyll a; haemocytometer; positive linearity.

\section{Introduction}

Botryococcus sp. is classified as freshwater green microalgae which could be found on temperate, continental, alpine, and tropical zones [1,2]. Botryococcus sp. has a potential for future biofuel source due to its high hydrocarbons production (up to $75 \%$ of algae by dry weight) [3]. Botryococcus sp. is one of the photosynthetic microalgae which need $\mathrm{CO}_{2}$, water, inorganic nutrients and light to grow. Most of the research studies regarding the effect of several growth factors on the microalgae production have been focusing on indoor culture systems [4]. However, few Botryococcus sp. growth studies conducted in outdoor conditions [4].
Mixing is critical in culturing microalgae. It is needed to ensure the microalgae spread evenly throughout the media cultures which help prevent accumulation of microalgae. Therefore, all the microalgae are evenly exposed to the nutrients and light [5]. Moreover mixing can avoid the outdoor culture from thermal stratification and increase gas exchange in the culture medium [5]. According to Barsanti and Gualtieri [5], there is a different mixing method such as shaking daily (small scale), aerating (small and big scale), using paddle wheels and jet pumps (big scale). This experiment was carried out to study the effect of mixing on the growth of microalgae by determining the cell concentration and chlorophyll a content of Botryococcus sp. culture.

*Corresponding author: mazhatarmizi@gmail.com

2018 UTHM Publisher. All right reserved.

e-ISSN: 2600-7924/penerbit.uthm.edu.my/ojs/index.php/jst 
Measuring the biomass concentration is important in most studies of algal physiology and biotechnology [6]. The procedure of counting cells is the first step of experiment to standardise the cell concentration between samples and minimizing error and differences in the results. Many quantitative methods can be used for determining the biomass of microalgae such as cell counts, optical density methods by directly use living culture or extracted pigments, and chemical determinations $[7,8,9]$. In these experiments, three different methods were used which are optical density (OD) reading using a spectrophotometer, counting cell using hemocytometer and chlorophyll a determination.

Optical density frequently used to measure the biomass of bacteria and other unicellular microorganism culture [10,11]. The productivity of microalgae culture mainly depends on the biomass concentration. Therefore optical density is the simplest method for estimating the biomass of microalgae by using a specific wavelength in spectrophotometer [12]. Chlorophyll a determination is another method that can be employed for determining the biomass of microalgae. Chlorophyll extraction involving three steps which are collecting the sample ( by centrifuge or filter), disperse the sample in an alcohol solvent and measuring the light absorbance of the chlorophyll by using spectrophotometer at a specific wavelength [13]. The composition of chlorophyll pigments in microalgae determine the biomass concentration of microalgae [14,15]. Usually, determination and calculation of microalgae were done in the laboratory under the microscope by using a hemocytometer.

\section{Methodology}

\subsection{Microalgae culture preparation}

Microalgae strain of Botryococcus $s p$. was isolated from a tropical rainforest located in Endau Rompin National Park, Johor, Malaysia (between N 02 30.711" E 103 20.984" and N $02^{\circ} 30.740^{\prime \prime}$ E $103^{\circ} 20.996^{\prime \prime}$ ). The initial stock of Botryococcus sp. was provided by STG1008 and was cultured and maintained on Bold's Basal medium (BBM) [16] by subculturing every two weeks. The culture was kept in an outdoor condition. Ten days fresh inoculum in the exponential period was used for the culture in this experiment.

\subsection{Experimental setup}

The Botryococcus sp. growth experiments were cultured in $300 \mathrm{ml}$ volume of BBM culture medium in $500 \mathrm{ml}$ Erlenmeyer flasks. Each flask was inoculated with an initial cell concentration $1 \times 10^{3}$ cells $/ \mathrm{mL}$ of microalgae based on the standard methods [17]. The concentration was determined by counting the stock microalgae using hemocytometer then insert the concentration value of the stock microalgae in equation 1 [18].

$\mathrm{C}_{1} \mathrm{~V}_{1}=\mathrm{C}_{2} \mathrm{~V}_{2}$

Where $C_{1}$ is the concentration of the stock culture (cells $/ \mathrm{ml}$ ), $\mathrm{V}_{1}$ is the volume of stock culture needed to inoculated in new culture $(\mathrm{ml}), \mathrm{C}_{2}$ is the initial cell concentration of the new culture (cell $/ \mathrm{ml})$, and $V_{2}$ is the volume of the new culture $(\mathrm{ml})$.

Three different treatments were employed: with aeration, by manual handshaking (two times daily for 5 minutes) and without shaking. The treatment with aeration was aerated by bubbling air using aeration pump. All the treatments were carried out in triplicate.

All the flasks were capped with sterile cotton plugs to allow the $\mathrm{CO}_{2}$ gasses exchange between medium to the atmosphere for the microalgae growth. All the culture medium, materials, and flasks used for the culture were sterilized for 15 minutes at $121^{\circ} \mathrm{C}$ by using autoclave to prevent any contamination. The cultures were grown under an outdoor natural condition with temperature ranging from $25.8^{\circ} \mathrm{C}$ to $35.5^{\circ} \mathrm{C}$, light intensity from $200 \mathrm{Lux}$ to $18000 \mathrm{Lux}$, and $\mathrm{pH}$ of 7 to 8 units for 24 days. Samples were taken at the certain time interval for analysis.

\subsection{Measurement of microalgae growth}

Three measurement methods of the Botryococcus $s p$. growth quantification were applied through this experiment.

\subsubsection{Counting cell}

Botryococcus sp. concentration was determined through cell counting by using Mod-Fuchs Rosential hemocytometer and observed under compound light microscope 
model Olympus BX43F-CCD. $1 \mathrm{ml}$ of sample in each flask was collected for the counting and gently shakes to homogenize the cells. The samples would be diluted first before counting if the samples were highly concentrated. The middle quadrant of the chambers (contains 9 squares) was chosen for counting the cells [19]. The density of cells counted per $\mathrm{ml}$ is calculated following the equation 2.

Number of cells / ml

$=\left[\right.$ Total counted cells $/\left(\sum s q \times \mathrm{A}_{\mathrm{sq}}\left(\mathrm{mm}^{2}\right) \times\right.$ chamber depth $(\mathrm{mm}) \times \mathrm{D})] \times 1000 \mathrm{~mm}^{3} / \mathrm{ml}$ (2)

Where, $\sum s q$ is total counted small square, $\mathrm{A}_{\mathrm{sq}}$ is small square surface area $\left(\mathrm{mm}^{2}\right)$ and D is sample dilution.

\subsubsection{Optical density (OD)}

The absorbance measurement was performed as an indirect measure of microalgae growth in culture media. The Botryococcus $s p$. growth was observed by measuring the optical density at $680 \mathrm{~nm}$ using spectrophotometer (Biomate 3S, UV-Visible spectrophotometer- Thermo Scientific). $3 \mathrm{ml}$ sample was collected every three days and always homogenize the sample first before taking for measurement. Distilled water was used as the blank. The efficiency of biomass growth was controlled by measuring the optical density (OD), which is defined as the absorption of visible radiation (adsorption peak of chlorophyll is at about $680 \mathrm{~nm}$ ).

\subsubsection{Chlorophyll-a}

Microalgae biomass can also be measured through the chlorophyll a (photosynthetic pigment) constituent in the cells. The procedure involving three phases which are isolating the microalgae, extracting the chlorophyll, and measuring the light absorbance of the pigments. $10 \mathrm{ml}$ of the microalgae culture was taken and filtered through a $0.45 \mu \mathrm{m}$ Whatman $\mathrm{GF} / \mathrm{C}$ membrane filter. The filter was thoroughly macerated with $90 \%$ acetone by using Teflon tissue grinder to mechanically disrupt the cells and extracting the pigments. The macerated sample with final volume $10 \mathrm{ml}$ was put under dark condition at cold temperature $4^{\circ} \mathrm{C}$ (at least two hours) to ensure the disrupted cells completely extracted. Then the extracted sample was centrifuged at $3500 \mathrm{rpm}$ for 20 minutes using centrifuge model MPW-351R. The $3 \mathrm{ml}$ supernatant was taken for the spectrophotometer analysis. The absorbance was reading at $750 \mathrm{~nm}, 664 \mathrm{~nm}$, and $665 \mathrm{~nm}$ before and after acidification with $0.1 \mathrm{ml}$ of $0.1 \mathrm{~N} \mathrm{HCl}$. Acetone $90 \%$ was used as the blank. The readings obtained were calculated through the monochromatic method equation (3) [17].

Chlorophyll a, $\mathrm{mg} / \mathrm{m}^{3}$

$=\frac{26.7\left[\left(664_{b}-750_{b}\right)-\left(665_{a}-750_{a}\right)\right] \times V_{1}}{V_{2} \times L}$

Where $\mathrm{V}_{1}$ is volume of extract $(\mathrm{L}), \mathrm{V}_{2}$ is volume of sample $\left(\mathrm{m}^{3}\right), \quad L$ is light path length or width of cuvette $(\mathrm{cm}), 750 \mathrm{~b}, 664_{b}, 665_{a}$, $750 a$ are absorbance of $90 \%$ acetone extract before (b) and after (a) acidification respectively.

\subsection{Growth analysis}

The growth curves of Botryococcus sp. were formed by plot the cell density against time based on the data measured from the culture samples collected at regular time interval (every 3 days). Specific growth rate, $(\mu /$ day), doubling time (td), and biomass productivity (cell/mL/day or $\mathrm{mg} / \mathrm{l} /$ day) was calculated from the exponential phase of the growth curves by using equations 3,4 , and 5 respectively $[20,21,22,23,24,25] . \mathrm{N}_{2}$ is the cell density at times $t_{2}$ and $N_{1}$ is the cell density at times $t_{1}$. The growth rate determination was used in comparing the growth result of the microalgae in different culture mode and the growth rate similarity between different measurement methods.

Specific Growth rate,$(\mu /$ day $)=\frac{\ln \left(N_{2} / N_{1}\right)}{t_{2}-t_{1}}$

Doubling time, $(\mathrm{td})=\frac{\ln 2}{\mu / \text { day }}$

Biomass productivity $=\frac{N_{2}-N_{1}}{t_{2}-t_{1}}$

The linearity graph shown correlation equation of cell number density and cell pigment density vs. absorbance at $680 \mathrm{~nm}$ were plotted and fitted. 


\subsection{Statistical analysis}

All experiments results are the average from the triplicates sample measurement. Data analysis and graph plotting were conducted by using Microsoft Office Excel Professional Plus 2010.

\section{Result and Discussion}

\subsection{Effect of mixing on cell count, optical density, and chlorophyll a measurement}

Botryococcus sp. growth on different mixing condition was estimated by determining their cell density, chlorophyll content and cell growth rate. From the growth curve, the exponential phase of Botryococcus sp. growth along 24 days culture for the aeration was starts from day 6 . It is earlier than no shake and manual shake that starts from day 10. The Botryococcus sp. growth for the aereation treatment is significantly superior with biomass productivity $10.74 \times 10^{6}$ cell/ml/day which is 4 times higher than manual shake and no shake $\left(2.7 \times 10^{6}\right.$ cell $/ \mathrm{ml} /$ day and $3.0 \times 10^{6} \mathrm{cell} / \mathrm{ml} /$ day). This followed by its biomass productivity on chlorophyll a content $0.7843 \mathrm{mg} / \mathrm{L} /$ day which is 5 times higher than manual and no shake $(0.1586 \mathrm{mg} / \mathrm{L} /$ day and $0.1545 \mathrm{mg} / \mathrm{L} /$ day $)$. The aeration enhance gas and liquid diffusion within the culture medium through the turbulent flow and bubbles formed which increase microalgae photosynthesis process and eventually speed up the growth [26]. Moreover, appropriate turbulent flow condition from aeration will help the microalgae growth rapidly through the efficiently nutrient (nitrogen and carbon) uptake in the culture medium and increase illumination condition [26]. The different of cell density, optical density reading and chlorophyll a content of Botryococcus sp. with different type of treatment was showed in Fig.
1. From Fig. 1 we can observe that three methods used for estimating the density of Botryococcus sp. was showed that treatment with aeration growth higher than treatment with manual shake and no shake.

The exponential phase of microalgae growth could be predicted when the points on the growth curves touched the straight line at least thrice [25]. The specific growth rate $(\mu /$ day) and doubling time (day) will be determined scientifically at the exponential phase based on the equation (5). The specific growth rate measure the microalgae growth ability under certain environmental conditions that has been set up. In addition the doubling time is the time required for the cells to divide. The higher the value of the doubling time the slower the growth of microalgae, while small value of doubling time indicated the rapid growth of microalgae. Table 1 show the specific growth rate $(\mu /$ day) and doubling time (day) for aeration, manual shake and no shake.

The specific growth rate higher in aeration treatment (cell count $=0.52 \mu /$ day; $\mathrm{OD}=0.52$ $\mu$ /day; Chlorophyll $\mathrm{a}=0.44 \mu$ /day) than manual shake (cell count $=0.26 \mu /$ day; $O D=$ $0.26 \mu /$ day; Chlorophyll $\mathrm{a}=0.17 \mu /$ day) and no shake (cell count $=0.23 \mu /$ day; $O D=0.32$ $\mu$ /day; Chlorophyll $a=0.20 \mu$ /day). Specific growth rate of aeration is two times than manual shake and no shake. Therefore, Botryococcus sp. ability to growth in the given condition which is aeration higher than no shake and manual shake. Moreover, doubling time for aeration (cell count $=1.32$ day; $\mathrm{OD}=$ 1.34 day; Chlorophyll a $=1.59$ day) lower than manual shake (cell count $=2.68$ day; $\mathrm{OD}=$ 2.66 day; Chlorophyll a $=4.17$ day) and no shake (cell count $=3.00$ day; $\mathrm{OD}=2.20$ day; Chlorophyll $\mathrm{a}=3.42$ day). Lower doubling time showed that Botryococcus sp. in aeration treatment required a short period to divide the cell and growing in the media. 


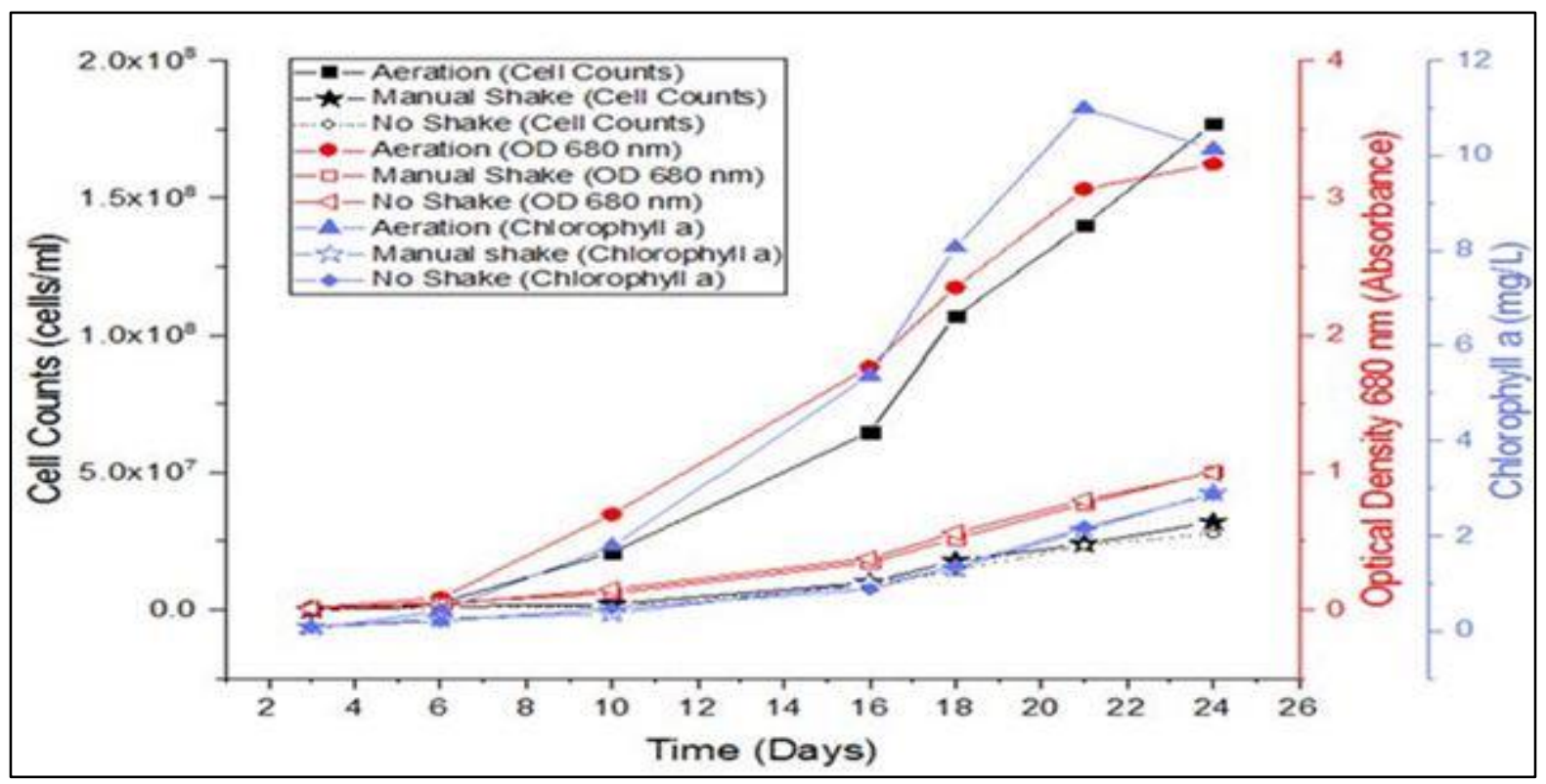

Fig. 1 Graph of Botryococcus sp. optical density reading, cell counts and chlorophyll a content in 24 days.

Table 1 Specific growth rate and doubling time of Botryococcus sp growth in the different culture. mode

\begin{tabular}{|l|l|l|l|l|l|l|l|l|}
\hline \multirow{2}{*}{$\begin{array}{l}\text { Culture } \\
\text { mode }\end{array}$} & \multicolumn{3}{|l|}{ Specific Growth Rate $(\mu /$ day) } & \multicolumn{4}{l|}{ Doubling Time (Day) } \\
\cline { 2 - 9 } & $\begin{array}{l}\text { Cell } \\
\text { Counts }\end{array}$ & $\begin{array}{l}\text { Optical } \\
\text { Density }\end{array}$ & Chlorophyll a & $\begin{array}{l}\text { Standard } \\
\text { Error }\end{array}$ & $\begin{array}{l}\text { Cell } \\
\text { Counts }\end{array}$ & $\begin{array}{l}\text { Optical } \\
\text { Density }\end{array}$ & Chlorophyll a & $\begin{array}{l}\text { Standard } \\
\text { Error }\end{array}$ \\
\hline Aeration & 0.52 & 0.52 & 0.44 & \pm 0.05 & 1.32 & 1.34 & 1.59 & \pm 0.15 \\
\hline $\begin{array}{l}\text { Manual } \\
\text { Shake }\end{array}$ & 0.26 & 0.26 & 0.17 & \pm 0.05 & 2.68 & 2.66 & 4.17 & \pm 0.86 \\
\hline $\begin{array}{l}\text { No } \\
\text { Shake }\end{array}$ & 0.23 & 0.32 & 0.20 & \pm 0.06 & 3.00 & 2.20 & 3.42 & \pm 0.62 \\
\hline
\end{tabular}

\subsection{Comparison and linearity relationship} between growth measurement methods

Microalgae growth pattern could be monitored by various measurement methods which are through cell counting, optical density and chlorophyll a content. From table 1 , the specific growth rate for aeration, manual shake and no shake from the three measurements shows a good growth curve agreement with only small deviation value within each other measurement. This result almost agreed with the previous finding from Butterwick, Heaney, and \& Talling [27], studies the comparison of cell count and optical density at $680 \mathrm{~nm}$ on growth of Asterionella formosa Hass. which achieved the same specific growth $1.2 \mu$ /day for both. Moreover linearity relationship in each culture mode between the three methods shows high positive linearity of $R$ value $(R \approx 1)$ with the least different 0.05 (Table 2).

Growth measurement through the microalgae chlorophyll a content help in qualitatively monitor the algae growth [28].In advance, Chlorophyll a analysis could be as health indicator of the algae culture rather than quantitatively measurement through cell counts [29].From the specific growth rate for all three culture mode, the cell number of Botryococcus sp. is increase much higher and faster than the chlorophyll a content and as a result the positive linearity between chlorophyll a and cell counts is less than the linearity relationship between cell counts and chlorophyll a with optical density at $680 \mathrm{~nm}$. This shown that Botryococcus sp. growing by used the media culture more than absorbing 
light energy. This finding also been reported by Held [30] on M. aeruginosa.

Cell counts and chlorophyll a shows higher positive linear relationship with the optical density than linear relationship between cell count and chlorophyll a (Table 2). According to the high linearity, optical density measurement was potentially chosen method used as a proxy estimation of microalgae cell concentration and chlorophyll pigment [31].The optical density was commonly used because of more accurate and less technique used which help in save the time and manpower [31,32]. In addition the optical density measurement can be used to estimate both qualitative through the turbidity and quantitative aspect of microalgae growth measurement by light absorption of known wavelength of the culture [31].

The determination of optical density wavelength is crucial in used optical density as rapid proxy for monitoring of growth culture and correlating with biomass [33]. The linearity relationship between cell counts and optical density for three different culture mode is slightly changed by standard deviation \pm 0.0148 indicate that linearity depending on the growth condition. This is because the wavelength $680 \mathrm{~nm}$ that been used is sensitive wavelengths (adsorption peak of chlorophyll), which means a slight change in the concentration of pigment could affect the relationship of OD with the cell concentration [31]. Therefore it is suggested to choose a wavelength away from the adsorption peak of pigment to get the constant relationship. In contrast, the optical density at $680 \mathrm{~nm}$ relationship with chlorophyll $\mathrm{a}$ is independent of the different culture mode with too small standard deviation \pm 0.004 since $680 \mathrm{~nm}$ is the absorption peak for the chlorophyll [29].

Table 2 Linearity relationship in between different growth measurement method.

\begin{tabular}{|c|c|c|c|}
\hline \multirow[b]{2}{*}{$\begin{array}{l}\text { Culture } \\
\text { mode }\end{array}$} & \multicolumn{3}{|l|}{ Linearity relationship ( R ) } \\
\hline & $\begin{array}{l}\text { Cell counts (cells/ml) vs OD } \\
680 \mathrm{~nm}\end{array}$ & $\begin{array}{l}\text { Chlorophyll a }(\mathrm{mg} / \mathrm{L}) \text { vs } \\
\text { OD } 680 \mathrm{~nm}\end{array}$ & $\begin{array}{l}\text { Cell counts }(\mathrm{Cells} / \mathrm{ml}) \\
\text { vs Chlorophyll a }(\mathrm{mg} / \mathrm{L})\end{array}$ \\
\hline Aeration & 0.9632 & 0.9866 & 0.9473 \\
\hline $\begin{array}{l}\text { Manual } \\
\text { Shake }\end{array}$ & 0.9817 & 0.9866 & 0.9756 \\
\hline No Shake & 0.9925 & 0.9929 & 0.9783 \\
\hline $\begin{array}{l}\text { Standard } \\
\text { Deviation }\end{array}$ & \pm 0.0148 & \pm 0.0036 & \pm 0.0172 \\
\hline
\end{tabular}

\section{Conclusion}

Aeration effectively enhanced the growth of microalgae by providing continuous mixing and carbon sources. Therefore the microalgae can consume the nutrient and carbon sources fairly and prevent them from sedimentation. Three methods used for measuring the biomass of microalgae which are optical density, counting cell using hemocytomete and chlorophyll a content have good positive linearity. The results of this study suggest that these three methods have the same precision to determining biomass of microalgae.

\section{Acknowledgements}

This study was supported by the FRGS grant vot 1476 . 


\section{References}

[1] Wolf, F. R., Nonomura, A. M. and Bassham, J. A. (1985). "Growth and Branched Hydrocarbon Production in a Strain of Botryococcus-Braunii (Chlorophyta)" in Journal of Phycology, Vol. 21. pp. 388-396.

[2] Metzger, P., Casadevall, E., Pouet, M. J., and Pouet, Y (1985). "Structure of Some Botryococcenes: Branched Hydrocarbons from the B Race of the Green Alga in Botryococcus Braunii" in Phytochem, Vol. 24. pp. 2995.

[3] Maxwell J.R., Douglas A.G., and Eglinton G., McCormick (1968). "The Botryococ-Cens-Hydrocarbons of Novel Structure from the Alga Botryococcus Braunii, Kutzing" in Phytochem, Vol. 7. pp 2157-71.

[4] Shimamura, R., Watanabe, S. ., Sakakura, Y., Shiho, M., Kaya, K. and, and Watanabe, M. M. (2012). "Development of Botryococcus Seed Culture System for Future Mass Culture" in Procedia Environmental Sciences, Vol. 15. pp 80-89.

[5] Barsanti, L. and Gualtieri P. (2014). Algae: Anatomy, Biochemistry, and Biotechnology, Second Edition, CRC Press.

[6] Griffiths, M. J., Garcin, C., Hille, R. P. V., and Harrison, S. T. L. (2011). "Interference by Pigment in the Estimation of Microalgal Biomass Concentration by Optical Density" in Journal of Microbiological Methods, Vol. 85. pp. 119-123.

[7] Strickland, J. D. H. and Parsons, T. R. (1972). A Practical Handbook of Seawater Analysis. 2nd edn. Bull. Fish. Res. Bd Can.

[8] Stein, J. R. (1973). Handbook of Phycological Methods: Culture Methods and Growth Measurements. Cambridge University Press, Cambridge.

[9] Hallegraeff, G. M. (1977). “A Comparison of Different Methods used for the Quantitative Evaluation of Biomass of Freshwater Phytoplankton" in Hydrobiologia, Vol. 55. pp. 145-165.

[10] Toennies, G., and Gallant, D.L. (1949). "The Relation Between
Photometric Turbidity and Bacterial Concentration" in Growth, Vol. 13. No. 1 pp. 7-20.

[11] Shuler, M.L., and Kargi, F. (2005). Bioprocess Engineering: Basic Concepts, 2nd ed. Pearson Education, Singapore

[12] Sandnes, J.M., Ringstad, T., Wenner, D., Heyerdahl, P.H., Källqvist, T., and Gislerød, H.R. (2006). "Real-time Monitoring and Automatic Density Control of Large-scale Microalgal Cultures using Near Infrared (NIR) Optical Density Sensors" in $J$. Biotechnol, Vol. 122. pp 209-215.

[13] Su, C.H., Fu, C.C., Chang, Y.C., Nair, G.R., Ye, J.L., Chu, I.M., and $\mathrm{Wu}$, W.T. (2008). "Simultaneous Estimation of Chlorophyll A and Lipid Contents in Microalgae by ThreeColor Analysis" in Biotechnol. Bioeng, Vol. 99. pp 1034-1039.

[14] Christon, J.H. (1997). Manual of Environmental Microbiology. ASM Press, Washington, DC.

[15] Ördög, V., Stirk, W.A., Bálint, P., van Staden, J., and Lovász, C. (2012). "Changes in Lipid, Protein and Pigment Concentrations in NitrogenStressed Chlorella Minutissima Cultures" in J. Appl. Phycol., Vol. 24. pp 907-914.

[16] Bischoff, H.W. and Bold H. C. (1963). Phycological Studies IV. Some Soil Algae from Enchanted Rock and Related Algal Species. Univ. of Texas Public, No.6318, Austin, Texas.

[17] APHA (2012). Standard Methods for the Examination of Water and Wastewater. American Public Health Association, Washington.

[18] Stephenson, F. H. (2010), Calculations for Molecular Biology and Biotechnology, Elsevier's Science and Technology, Oxford, U.K.,

[19] Santos, K. R. and Mariano, A. B. (2014). "Determination of Optimal Algae Concentration for Continuous Growth of Scenedesmus $\mathrm{Sp}$. in CHU and Modified CHU Media" in Thermal Engineering, Vol. 13. No. 2 pp. 52-58.

[20] Zhu, L., Wang, Z., Shu, Q., Takala, J., Hiltunen, E., Feng, P., Yuan, Z. (2013). "Nutrient Removal and 
Biodiesel Production by Integration of Freshwater Algae Cultivation with Piggery Wastewater Treatment" in Water Research, Vol. 47. No 13 pp. 4294-4302.

[21] Komolafe, O., Velasquez Orta, S.B., Monje-Ramirez, I., Yáñez Noguez, I., Harvey, A.P., Orta Ledesma, M.T. (2014). "Biodiesel Production from Indigenous Microalgae Grown in Wastewater" in Bioresource Technology, Vol. 154. pp. 297-304.

[22] Asmare, A.M., Demessie, B.A., Murthy, G.S. (2013). "Baseline Study on the Dairy Wastewater Treatment Performance and Microalgae Biomass Productivity of an Open Pond Pilot Plant" in Ethiopian Case, Vol. 4. No 4 pp 88-109.

[23] Issarapayup, K., Powtongsook, S., Pavasant, P. (2009). "Flat Panel Airlift Photobioreactors for Cultivation of Vegetative Cells of Microalga Haematococcus Pluvialis" in Journal of Biotechnology, Vol. 142. No 3-4 pp. 227-232.

[24] Wang, L., Min, M., Li, Y., Chen, P., Chen, Y., Liu, Y., Wang, Y., Ruan, R. (2010) "Cultivation of Green Algae Chlorella Sp. in Different Wastewaters from Municipal Wastewater Treatment Plant" in Applied Biochemistry and Biotechnology, Vol. 162. No. 4 pp 1174- 1186.

[25] Andersen, R.A., (2005). Algal Culturing Techniques 1st Edition, Elsevier Academic Press. Burlington, USA.

[26] Zhao, B., Zhang, Y., Xiong, K., Zhang, Z., Hao, X. and Liu, T. (2011). "Effect of Cultivation Mode on Microalgal Growth and $\mathrm{CO}_{2}$ Fixation" in Chemical Engineering Research and Design, Vol 89. pp 1758-1762.

[27] Butterwick, C., Heaney, S. I. and Talling, J. F. (1982). "A Comparison of Eight Methods for Estimating the Biomass and Growth of Planktonic Algae in British Phycological Journal, Vol. 17. No. 1 pp. 69-79.

[28] Becker, E. W. (1994). Microalgae: Biotechnology and Microbiology, Cambridge University Press.

[29] Jia, F., Kacira, M., A., and Ogden, K. L. (2015). "Multi-Wavelength Based
Optical Density Sensor for

Autonomous Monitoring of Microalgae" in Sensors, Vol. 15. No. 9 pp. 22234-22248.

[30] Held, P. (2011). "Monitoring of Algal Growth Using their Intrinsic Properties Use of a Multi-Mode Monochromator-based Microplate Reader for Biofuel Research" in Biofuel Research, pp. 1-5.

[31] Myers, J. A., Curtis, B. S. and Curtis, W. R. (2013). "Improving Accuracy of Cell and Chromophore Concentration Measurements using Optical Density" in BMC Biophysics, Vol. 6. No. 4 pp. 15.

[32] Sivakumar and Rajendran (2013). "Growth measurement technique of microalgae" in Current Science Journal, Vol. 7. pp 52-54.

[33] Sezonov, G., Joseleau-Petit, D., and D’Ari R. (2007). "Escherichia Coli Physiology in Luria-Bertani Broth" in J Bacteriol, Vol. 189. pp. 8746. 